\title{
Efektifitas Edukasi Kesehatan Menggunakan Media Booklet terhadap Self Care Management Pasien Penyakit Ginjal Kronik di Unit Hemodialisa
}

\author{
Dani Prastiwi ${ }^{1}$, Ari Sukmarini ${ }^{2}$, Isrofah $^{3}$ \\ 1,2,3 Universitas Pekalongan, Jawa Tengah, Indonesia \\ ${ }^{2}$ RSUD Kraton Kabupaten Pekalongan, Jawa Tengah, Indonesia \\ Corresponding Author: dani.unikal@gmail.com
}

\begin{abstract}
Abstrak
Pasien penyakit ginjal kronik membutuhkan kemampuan dalam melakukan perawatan pada dirinya sendiri. Kemampuan self care perlu ditingkatkan dengan membekali pengetahuan pasien sehingga kualitas hidupnya meningkat. Salah satu upaya untuk meningkatkan pengetahuan pasien dapat dilakukan dengan memberikan pendidikan kesehatan dengan menggunakan media booklet. Penelitian ini bertujuan untuk mengetahui efektifitas edukasi dengan menggunakan media booklet terhadap self care management pasien penyakit ginjal kronik di unit hemodialisa di RSUD Kraton Kabupaten Pekalongan. Penelitian ini merupakan riset quasy experiment dengan menggunakan pre-test and posttest with control group design. Sampel yang digunakan dalam penelitian ini berjumlah 40 pasien dengan pembagian 20 pasien kelompok intervensi dan 20 pasien kelompok kontrol. Data dianalisa secara bivariat menggunakan uji paired t-test. Hasil analisa data menunjukkan adanya pengaruh yang signifikan pemberian edukasi kesehatan tentang perawatan mandiri penyakit ginjal kronik dengan media booklet terhadap self care management pada pasien yang menjalani hemodialisis di RSUD Kraton Kabupaten Pekalongan $(\rho=0,000)$. Oleh karena itu, intervensi ini dapat menjadi inovasi bagi pelayanan keperawatan bagi pasien hemodialisis.
\end{abstract}

Kata kunci: booklet, hemodialisis, penyakit ginjal kronik, self care management

\begin{abstract}
Patients with chronic kidney disease requires care in their own care (self care). Self care needs to improve by appropriate knowledge so that patient's quality of life will improve. One effort to improve patient's knowledge can be done by providing health education using booklet. This study aims to explore the effectiveness of health education by using booklet towards self care management of chronic kidney disease patients in haemodialysis unit at Kraton Hospital Pekalongan. This study applied quasy experimental reseacrh design pretest and posttest with control group. Samples are taken 40 respondents who are devided in two groups. The bivariate analyse method used in this research is paired t-test. There was a significant influence of health education about chronic kidney disease with booklet on self care management in patients who got through hemodialysis treatment at Kraton Hospital, Pekalongan $(\rho=0.000)$. So that, this intervention can be an innovation in nursing care for hemodialysis patients.
\end{abstract}

Keywords: booklet, hemodialysis, chronic kidney disease, self care management 
Jurnal IImu Keperawatan Medikal Bedah 3 (1), Mei 2020, 1-76

ISSN 2338-2058 (print), ISSN 2621-2986 (online)

\section{PENDAHULUAN}

Indonesia merupakan negara dengan tingkat penderita penyakit ginjal kronik cukup tinggi. Persatuan Nefrologi Indonesia (PERNEFRI) tahun 2011 melaporkan bahwa diperkirakan ada 70 ribu penderita penyakit ginjal kronik di Indonesia, namun yang terdeteksi menderita penyakit ginjal kronik tahap akhir dan menjalani hemodialisis hanya sekitar 4-5 ribu. Banyak yang telah menjalani terapi dialisis meninggal dunia karena mahalnya biaya yang dikeluarkan untuk berobat dan proses dialisis (Fransisca, 2011). Tujuan hemodialisis adalah untuk memperbaiki komposisi cairan sehingga mencapai keseimbangan cairan yang diharapkan untuk mencegah kekurangan atau kelebihan cairan yang dapat menyebabkan efek yang signifikan terhadap komplikasi kardiovaskuler dalam jangka panjang (Wilson, 2012).

Pasien penyakit ginjal kronik yang menjalani hemodialisis memiliki permasalahan yang kompleks terhadap kondisi fisik, psikologis, sosial, ekonomi, dan spiritual pasien (Farida, 2010). Hemodialisis memiliki dampak tertentu pada pasien yang berkepanjangan biasanya gejala fisik seperti jantung berdebar, berkeringat, rasa sesak napas, gangguan tidur, mudah lelah, sering kencing, dan mulut kering. Peningkatan prevalensi kejadian yang terjadi pada pasien hemodialisis dapat disebabkan oleh berbagai faktor salah satunya adalah ketidaktepatan dalam melakukan self care management.

Self management merupakan serangkaian teknis untuk mengubah perilaku, pikiran, dan perasaan yang meliputi pemantauan diri, reinforcement yang positif, perjanjian dengan diri sendiri, dan penguasaan terhadap rangsang. Ketidakmampuan melaksanakan self care dapat mengakibatkan gejala yang dirasakan pasien semakin berat dan menjadi penyebab pasien menjalani hospitalisasi. Oleh sebab itu, upaya yang dilakukan untuk menekan timbulnya gejala penyakit yang buruk serta menghindari rehospitalisasi bagi pasien yaitu meningkatkan kemampuan self care tersebut (Britz \& Dunn, 2010; Discroll et al, 2010). Salah satu upaya untuk meningkatkan pengetahuan pasien dapat dilakukan dengan memberikan pendidikan kesehatan dengan menggunakan media massa seperti booklet, leaflet, flyer, flipcart, rubrik, poster, serta media elektronik meliputi televisi, radio, video, dan slide (Sulaiman, 2008).

Berdasarkan wawancara pada tanggal 26 Februari 2018 di unit hemodialisis RSUD Kraton Kabupaten Pekalongan dengan 10 pasien hemodialisis didapatkan bahwa 6 (52\%) pasien 
mengatakan kurang termotivasi dalam menjalani diit, pembatasan cairan, dan 4 (48\%) pasien mengatakan sudah bosan minum obat terus menerus dalam jumlah yang banyak. Mereka menganggap dengan dilakukannya terapi hemodialisis sudah dapat mengatasi masalah yang dialaminya tanpa melakukan diet sehingga lebih dari 50\% pasien mengalami gangguan. Pasien penyakit ginjal kronik yang menjalani hemodialisis sering mengalami malnutrisi, kesulitan dalam membatasi asupan cairan yang masuk, inflamasi, dan penurunan kualitas hidup sehingga memiliki morbiditas dan mortalitas yang lebih tinggi dibanding populasi normal. Edukasi kesehatan dengan media booklet belum pernah ada di RSUD Kraton Kabupaten Pekalongan, dan meskipun tersedia leaflet di unit hemodialisis tetapi tidak optimal didistribusikan.

\section{METODE PENELITIAN}

Penelitian ini merupakan penelitian quasy experiment dengan rancangan pre-test and post-test design. Sampel ditentukan dengan cara simple random sampling dengan memperhatikan kriteria tertentu seperti: mampu membaca dan menulis, kooperatif, mampu melakukan aktivitas mandiri, dan bersedia menjadi responden. Jumlah sampel yang digunakan 20 responden untuk masing-masing kelompok intervensi dan kelompok kontrol yang menjalani hemodialisis di RSUD Kraton Kabupaten Pekalongan. Pengumpulan data menggunakan kuesioner self care of CKD index yang dimodifikasi dan dikembangkan oleh Riegel, et al (2004). Penelitian ini memperhatikan etika penelitian seperti informed consent, anonymity, dan independence to refuse. 
Jurnal IImu Keperawatan Medikal Bedah 3 (1), Mei 2020, 1-76

ISSN 2338-2058 (print), ISSN 2621-2986 (online)

\section{HASIL DAN PEMBAHASAN}

\section{A. Hasil Penelitian}

Adapun karakteristik responden dalam penelitian ini dapat dilihat pada tabel 1.

Tabel 1. Distribusi Karakteristik Responden di Unit Hemodialisa

RSUD Kraton Kabupaten Pekalongan ( $\mathrm{n}=40)$

\begin{tabular}{lcccccc}
\hline \multirow{1}{*}{ Karakteristik } & \multicolumn{2}{c}{$\begin{array}{c}\text { Kelompok } \\
\text { Eksperimen } \\
(\mathbf{n = 2 0})\end{array}$} & $\begin{array}{c}\text { Kelompok Kontrol } \\
(\mathbf{n = 2 0})\end{array}$ & \multicolumn{2}{c}{ Jumlah } \\
\cline { 2 - 7 } & $\mathrm{f}$ & $\%$ & $\mathrm{f}$ & $\%$ & $\mathrm{f}$ & $\%$ \\
\hline Usia : & & & & & & \\
17-25 Tahun & 0 & 0,0 & 2 & 10,0 & 2 & 5,0 \\
26-35 Tahun & 2 & 10,0 & 2 & 10,0 & 4 & 10,0 \\
36-45 Tahun & 4 & 20,0 & 8 & 40,0 & 12 & 30,0 \\
46-55 Tahun & 13 & 65,0 & 5 & 25,0 & 18 & 45,0 \\
56-65 Tahun & 1 & 5,0 & 1 & 5,0 & 2 & 5,0 \\
>65 Tahun & 0 & 0,0 & 2 & 10,0 & 2 & 5,0 \\
\hline Pendidikan : & & & & & & \\
SD & 1 & 5,0 & 2 & 10,0 & 3 & 7,5 \\
SMP & 2 & 10,0 & 5 & 25,0 & 7 & 17,5 \\
SMA & 4 & 20,0 & 4 & 20,0 & 8 & 20,0 \\
Perguruan Tinggi & 13 & 65,0 & 9 & 45,0 & 21 & 52,5 \\
\hline Pekerjaan : & & & & & & \\
Tidak bekerja & 2 & 10,0 & 5 & 25,0 & 7 & 17,5 \\
Buruh/ Karyawan & 4 & 20,0 & 5 & 25,0 & 9 & 22,5 \\
PNS/ Pensiunan & 11 & 55,0 & 9 & 45,0 & 20 & 50,0 \\
Pedagang & 3 & 15,0 & 1 & 5,0 & 4 & 10,0 \\
\hline
\end{tabular}

Berdasarkan tabel 1 dapat diketahui bahwa usia kelompok intervensi mayoritas pada rentang usia 45-55 tahun (65\%) dan usia pada kelompok kontrol mayoritas pada rentang 36-45 tahun (40\%). Berdasarkan tingkat pendidikan, mayoritas perguruan tinggi baik pada kelompok intervensi (65\%) maupun kelompok kontrol (45\%), berdasarkan pekerjaan mayoritas sebagai PNS/ Pensiunan baik pada kelompok intervensi (55\%) dan kelompok kontrol (45\%).

Adapun pengaruh edukasi kesehatan dengan menggunakan media booklet terhadap self care management pada pasien yang menjalani hemodialisis pada kedua kelompok tersaji dalam tabel 2 di bawah ini. 
Jurnal IImu Keperawatan Medikal Bedah 3 (1), Mei 2020, 1-76

ISSN 2338-2058 (print), ISSN 2621-2986 (online)

Tabel 2. Efektifitas Penggunaan Media Booklet terhadap Self Care Management pada Pasien Penyakit Ginjal Kronik di Unit Hemodialisa RSUD Kraton Kabupaten Pekalongan $(\mathrm{n}=40)$

\begin{tabular}{lcccc}
\hline \multicolumn{1}{c}{ Variabel } & Kelompok & Mean \pm SD & $\Delta$ Mean & $\boldsymbol{\rho}$ \\
\hline $\begin{array}{l}\text { Self care } \\
\text { management }\end{array}$ & Intervensi & & & \\
& Pretest & $50,0 \pm 12,3$ & 15 & 0,000 \\
& Posttest & $65,0 \pm 7,41$ & & \\
& & & 0,603 \\
& Kontrol & & 0,7 & \\
\hline
\end{tabular}

Berdasarkan tabel 2 dapat diketahui nilai rata-rata self care mangement pada pasien yang menjalani hemodialisis sebelum diberikan edukasi kesehatan melalui media booklet yaitu $50,0 \pm 12,13$ pada kelompok eksperimen dan 47,0 $\pm 14,99$ pada kelompok kontrol. Nilai rata-rata self care mangement pada pasien yang menjalani hemodialisis setelah diberikan edukasi

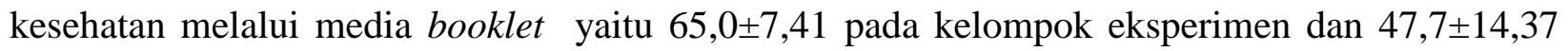
pada kelompok kontrol. Hasil analisis lebih lanjut menunjukkan pada kelompok kontrol, didapatkan nilai $\rho=0,603 \quad(\alpha>0,05)$ yang artinya bahwa tidak ada perbedaan self care management yang signifikan antara pretest dan posttest pada kelompok kontrol. Pada kelompok intervensi, nilai $\rho=0,000(\alpha<0,05)$ yang berarti bahwa ada pengaruh perbedaan yang signifikan terhadap self care management sebelum dan sesudah dilakukan edukasi kesehatan menggunakan media booklet.

\section{B. Pembahasan}

Penyakit ginjal kronis (PGK) merupakan salah satu penyakit kronis yang perkembangannya lambat namun progresif, irreversibel, dan samar dengan prevalensi yang terus meningkat. Pasien PGK memiliki kompleksifitas masalah pada kondisi fisik, psikologis, sosialekonomi, dan spiritual sehingga membutuhkan self care management.

Berdasarkan hasil penelitian diketahui bahwa proporsi usia tertinggi pada kelompok usia 46-55 tahun. Penelitian ini sejalan dengan dengan penelitian Gonzales, et al. juga membuktikan bahwa terdapat hubungan antara usia dengan penurunan nilai GFR, bertambahnya usia akan mempengaruhi anatomi, fisiologi dan sitologi pada ginjal. Setelah usia 30 tahun, ginjal akan mengalami atrofi dan penebalan kortek ginjal akan berkurang sekitar $20 \%$ setiap dekade. 
Jurnal IImu Keperawatan Medikal Bedah 3 (1), Mei 2020, 1-76

ISSN 2338-2058 (print), ISSN 2621-2986 (online)

Perubahan lain yang akan terjadi seiring dengan bertambahnya usia berupa penebalan membran basal glomerulus, ekspansi mesangium glomerular dan terjadinya deposit protein matrik ekstraseluler sehingga menyebabkan glumerulosklerosis. (Baradero \& Siswandi, 2010).

Pasien penyakit ginjal kronik yang menjalani hemodialisis di RSUD Kraton Kabupaten Pekalongan kurang termotivasi dalam menjalani diet, pembatasan cairan, dan sudah bosan minum obat. Peran perawat disini membantu pasien untuk memahami bagaimana cara management diri agar tidak terjadi komplikasi dari penyakt ginjal kronik, diperlukan pengetahuan dan kepercayaan diri yang kuat dari pasien penyakt ginjal kronik dalam menjalani terapi atau perawatan pasien dengan penyakit ginjal kronik.

Edukasi merupakan pengembangan serta penyediaan perintah melalui kebiasaan pembelajaran yang terkontrol sehingga diperoleh perilaku kondusif untuk selalu hidup sehat pada individu, keluarga, kelompok, dan komunitas (Dotcherman \& Bulechek, 2013). Edukasi juga merupakan pembelajaran yang didasari oleh proses interaktif dan juga upaya dalam menambah pengetahuan baru, sikap, ketrampilan melalui pembelajaran praktik dan pengalaman (Smeltzer \& Bare, 2008) menurut Edelman dan Mandle (2010) tujuan dilakukan edukasi kesehatan yaitu supaya seseorang bisa memperoleh kesehatan yang optimal melalui usahanya sendiri.

Pemberian edukasi dengan media atau alat peraga dapat mengubah pengetahuan melalui pancaindera yang ditangkap oleh seseorang. Media atau alat peraga adalah alat yang digunakan oleh pendidik untuk membantu dan menerangkan sesuatu dalam proses pendidikan atau pengajaran. Media bermanfaat menimbulkan minat sasaran, merangsang sasaran untuk meneruskan pesan pada orang lain, dan memudahkan penyampaian informasi. Media booklet adalah buku yang tipis dan lengkap informasinya, yang memudahkan media tersebut untuk dibawa (Satmoko dkk, 2010). Booklet berisi informasi yang jelas, tegas, dan mudah dimengerti. Selain itu, booklet juga berisi tulisan dan gambar (Suiraoka \& Supariasa, 2012). Hal tersebut sesuai dengan penelitian yang dilakukan oleh Wibowo (2013) bahwa ada pengaruh pengetahuan responden setelah dilakukan pendidikan kesehatan dengan metode buku saku/ booklet.

Berdasarkan tabel 2, menunjukkan pada kelompok kontrol, didapatkan nilai $\rho$ value $=0,603(\alpha>0,05)$ yang artinya bahwa tidak ada perbedaan self care management yang signifikan pada kelompok kontrol. Pada kelompok intervensi, nilai $\rho=0,000(\alpha<0,05)$ yang 
Jurnal IImu Keperawatan Medikal Bedah 3 (1), Mei 2020, 1-76

ISSN 2338-2058 (print), ISSN 2621-2986 (online)

berarti bahwa ada pengaruh perbedaan yang signifikan terhadap self care management sebelum dan sesudah diberikan edukasi kesehatan menggunakan media booklet.

Pemberian edukasi dengan menggunakan media booklet dapat meningkatkan pengetahuan. Booklet merupakan alat bantu berbentuk buku, dilengkapi dengan tulisan maupun gambar yang disesuaikan dengan sasaran pembacanya. Informasi yang ada dalam booklet disusun dengan jelas dan rinci, sehingga dapat ditangkap dengan baik oleh sasaran pendidikan dan tidak menimbulkan kesalahan persepsi. Penggunaan media booklet sebagai alat bantu dalam pemberian edukasi kesehatan kepada pasien penyakit ginjal kronik akan membuat sasaran pendidikan lebih mudah memahami informasi yang disampaikan dibandingkan penyampaian informasi hanya secara lisan. Sasaran pendidikan dapat mengamati langsung gambar dan tulisan yang merupakan penjelasan terhadap gambar yang ada dalam media tersebut (Maulana, 2010).

Penggunaan media booklet dalam penelitian ini memiliki keunggulan atau kelebihan dibandingkan dengan media lain. Hal ini disebabkan dengan menggunakan media booklet pasien dapat mempelajari setiap saat karena didesain berbentuk buku. Pasien dapat belajar mandiri, informasi dapat dibagi dengan keluarga, dan informasi yang disampaikan relatif lebih banyak dibandingkan dengan penggunaan media lain. Booklet yang diberikan berisi informasi tentang perawatan mandiri pasien penyakit ginjal kronik, seperti pengaturan makanan, pembatasan cairan, obat-obatan, dan akses vaskuler. Kemampuan pasien penyakit ginjal kronik dalam melakukan self care management merupakan tujuan utama penggunaan media booklet ini.

Self care management mendorong pasien menggunakan sumber daya yang ada untuk mengatasi gejala yang dialami terutama pada pasien penyakit kronis. Self care management memfasilitasi pasien untuk aktif melakukan aktifitas perawatan mandiri dan diperlukan kerjasama dengan tenaga kesehatan lain. Pendidikan kesehatan akan mendorong kemandirian pasien sehingga dapat mengelola penyakitnya secara mandiri. Peningkatan pengetahuan yang diperoleh pasien penyakit ginjal kronis di RSUD Kraton diperoleh hasil signifikan. Keyakinan diri pasien meningkat terhadap pengelolaan penyakit ginjal kronik. Dukungan dari keluarga dan orang-orang terdekat dapat mempengaruhi peningkatan perilaku self care management pasien penyakit ginjal kronik. Petugas kesehatan sebagai fasilitator dan pengawas dalam terapi juga sangat ikut mengambil peran. Hal ini sesuai dengan pernyataan Rogers dikutip dari Syarifudin 
Jurnal IImu Keperawatan Medikal Bedah 3 (1), Mei 2020, 1-76

ISSN 2338-2058 (print), ISSN 2621-2986 (online)

(2009) yang mengatakan bahwa penerimaan perilaku yang didasari oleh pengetahuan dan sikap yang positif (membentuk kepatuhan), maka perilaku tersebut akan bertahan lama. Tetapi sebaliknya, jika perilaku yang tidak didasari dengan pengetahuan dan sikap yang positif maka perilaku tersebut tidak bertahan lama.

\section{KESIMPULAN}

Dari hasil analisis self care managemet sebelum dan sesudah diberikan edukasi kesehatan tentang penyakit ginjal kronik dengan hasil uji paired t-test didapatkan nilai $p$ adalah 0,000 $(\alpha<0,05)$ artinya terdapat pengaruh yang signifikan edukasi kesehatan dengan menggunakan media booklet terhadap self care management pada pasien penyakit ginjal kronik. Oleh karena itu, intervensi ini dapat menjadi inovasi bagi pelayanan keperawatan bagi pasien hemodialisis.

\section{DAFTAR PUSTAKA}

Britz, J. A \& Dunn, K.S. (2010). Self care and quality of life among patients with heart failure. Journal of The American Academy of Nursing Practi Croneres, 22, 480 - 487.

Brunner \& Suddarth, (2013). Keperawatan medikal bedah. Edisi 12 (Terjemahan). Jakarta: EGC.

Dotcherman \& Bulechek. (2013). Nursing intervention classification. (Terjemahan). Jakarta: EGC.

Edelman \& Mandle. (2010). Health promotion through the life span. Canada: Mosby Elsevier.

Farida, A. (2010). Pengalaman klien hemodialisa terhadap kualitas hidup di RS Fatmawati. Jakarta. Tesis. Tidak dipublikasikan.

Fransisca, dkk. (2011). Waspadalah 24 penyebab gagal ginjal rusak. Jakarta: Cerdas Sehat.

Maulana, Heri, D.J. (2010). Promosi kesehatan. Jakarta : Penerbit Buku Kedokteran EGC.

RSUD Kraton Kabupaten Pekalongan. (2017). Data rekam medik jumlah pasien gagal ginjal yang menjalani hemodialisis. Tidak dipublikasikan.

Satmoko, S., dan Astuti, H.T. (2010). Pengaruh bahasa booklet pada peningkatan pengetahuan peternak sapi perah tentang inseminasi buatan di Kelurahan Nongkosawit, Kecamatan Gunungpati, Kota Semarang. Jurnal Penyuluhan ISSN: 1858-2664 September 2006 Vol. 2 No. 2.

Suiraoka dan Supariasa, N. (2012). Media pendidikan kesehatan. Yogyakarta: Graha Ilmu.

Prastiwi, Sukmarini, \& Isrofah / Efektifitas edukasi kesehatan menggunakan media booklet... 53 
Jurnal IImu Keperawatan Medikal Bedah 3 (1), Mei 2020, 1-76

ISSN 2338-2058 (print), ISSN 2621-2986 (online)

Sulaiman, A. H. (2008). Media audio visual untuk pengajaran, penerangan, dan penyuluhan. Jakarta: PT Gramedia.

Suyono. (2015). Buku ajar ilmu penyakit dalam. Jakarta: Balai Penerbit FK UI.

Syaifudin, Y.F. (2009). Promosi kesehatan untuk mahasiswa kebidanan: Jakarta : TIM.

PERNEFRI. (2011). Konsensus manajemen anemia pada penyakit ginjal kronik. Jakarta: Perhimpunan Nefrologi (PERNEFRI); 4-40.

Persell, D.S., Kaeting, dan Nancy, L. (2010). Evaluation of medication self management education program for eldery with hypertention living in the community.

Wibowo, S \& Suryani, D. (2013). Pengaruh promosi kesehatan metode audiovisual dan metode booklet terhadap peningkatan pengetahuan penggunaan monosodium glutamat (MSG) pada ibu rumah tangga. Jurnal Kesmas ISSN; 1978-0575, VOL.7 No.2, http://lib.ugm.ac.id diakses tanggal 18 September 2018.

Wilson. (2012). The basic concept of hemodialysis. London : Braille Tindal. 